\title{
Comparison of the Damaged Area Caused by an Agricultural Dam-Break Flood Wave Using HEC-RAS and UAV Surveying
}

\author{
Chung-Gil Jung, Seong-Joon Kim \\ Dept. of Civil, Environmental and Plant Eng., Konkuk University, Seoul, South Korea \\ Email: kimsj@konkuk.ac.kr
}

How to cite this paper: Jung, C.-G. and Kim, S.-J. (2017) Comparison of the Damaged Area Caused by an Agricultural DamBreak Flood Wave Using HEC-RAS and UAV Surveying. Agricultural Sciences, 8, 1089-1104.

https://doi.org/10.4236/as.2017.810079

Received: September 6, 2017

Accepted: October 10, 2017

Published: October 13, 2017

Copyright ( $\odot 2017$ by authors and Scientific Research Publishing Inc. This work is licensed under the Creative Commons Attribution International License (CC BY 4.0).

http://creativecommons.org/licenses/by/4.0/

\begin{abstract}
This study examines the usability of unmanned aerial vehicle (UAV) data surveyed just after an agricultural reservoir collapse by comparing the survey results with the simulation results of the HEC-RAS (Hydrologic Engineering Centers River Analysis System) flood wave propagation to the downstream areas. A $61,400 \mathrm{~m}^{3}$ storage dam broken by $89.0 \mathrm{~mm}$ (over $30.0 \mathrm{~mm} / \mathrm{hr}$ rainfall intensity) of rainfall on August $21^{\text {st }}, 2014$ was considered. The reservoir water capacity curve and downstream damaged areas were estimated by drone surveying 3 days after the dam break. The flood wave by the overtopped dam break was propagated using the HEC-HMS (Hydrologic Engineering Centers Hydrological Modeling System) reservoir inflow from the watershed. The model results showed flood inundation depths of 0.1 to $2.2 \mathrm{~m}$, mainly in rice paddy areas along the stream, and the overtopped dam-break scenario exhibited 59\% correspondence with the drone-surveyed areas.
\end{abstract}

\section{Keywords}

Ungauged Agricultural Catchment, Drone Survey, HEC-HMS, HEC-RAS, Inundation Map

\section{Introduction}

Dam break is a serious devastating disaster that occurs around the world and causes large amounts of damage to people worldwide [1]. In South Korea, there are 17,531 agricultural reservoirs, with $88.4 \%, 9.1 \%$, and $2.5 \%$ having storage capacities of less than 0.1 million $\mathrm{m}^{3}$, between 0.1 and 1.0 million $\mathrm{m}^{3}$, and over 1.0 million $\mathrm{m}^{3}$, respectively. These reservoirs now hold $55 \%$ of the irrigation water among the total supply to 447,000 ha, with a total capacity of 2.78 billion $\mathrm{m}^{3}$. 
However, old reservoirs often do not have adequate structural stability, and the recent record-breaking rainfall events have increased the threats of hydrological stability. Among these reservoirs, 52\% are over 70 years old, $22.2 \%$ are over 50 years old, and $22.6 \%$ are over 30 years old.

Recently, many studies on dam break have been performed, with the resulting damaged areas estimated using many approaches. Carling et al. [2] conducted dam-breach modeling with 1 - and 2-dimensional hydraulic models that were specially developed for ice dam failures via piping and overtopping. Sarhadi et al. [3] presented a methodology to assess floodplain mapping at ungauged rivers via 1-dimensional hydraulic inundation modeling. They used high-resolution digital terrain models (DTMs), land use characteristics, and channel properties to identify the critical and vulnerable areas affected by floods in different return periods. You et al. [1] reviewed earth-rock dam safety using high-resolution digital surface model (DSM) data. Evangelista et al. [4] presented the application of a multi-stage first-order centered scheme GMUSTA (Generalized MUlti STAge) to solve a two-phase flow model with four equations. Prakash et al. [5] attempted to simulate the impact of dam-wall failure scenarios using the Smoothed Particle Hydrodynamics (SPH) method on flood inundation, including modeling of dam-wall fragments.

The prediction of flood magnitude at ungauged reaches is an important task in designing river engineering and hydraulic structures and remains a fundamental challenge for hydrologists [6]. Although considerable research has been conducted based on available information for dam-break problems, the lack of data from ungauged regions still remains an issue in providing accurate predictions of flood magnitude, which is a key factor for reliable flood inundation mapping [3]. The most important data required to perform hydrologic and hydraulic dam-break simulations relate to the topographic relationship between the reservoir water level and storage and the cross sections of the stream, including protected lowlands.

A high-resolution DTM or DSM is critical to extract the details of the channel topography, obtain the water surface elevations at the cross sections, and simulate flood inundation and depth [3] [7]. Many studies have considered the HEC-RAS (Hydrologic Engineering Centers River Analysis System) performance by high-resolution DSM extracted from new data sources, such as Light Detection and Ranging (LiDAR) and Synthetic Aperture Radar (SAR) data [8]-[13]. In addition to these various studies, the unmanned aerial vehicle (UAV) remote sensing is an easy and increasingly popular approach to obtain high-quality terrain data. The UAV, also known as a drone, is an aircraft combined with a ground control station and communication support equipment that is flown without a pilot on board and can be remote controlled automatically or semi-automatically by using preprocessed programs or artificial intelligence. Recently, many studies on dam break have been performed, with the resulting damaged areas estimated using many approaches. The technology of UAV remote 
sensing can quickly detect changes in disaster information at the micro and/or mesoscale without the effect of bad or cloudy weather and with a spatial resolution of at least $0.2 \mathrm{~m}$ [14]. The potential for the use of UAVs for non-contact flow measurement has been identified [15]. Currently, many researches using UAV are going on now for monitoring of various flow conditions [16] [17]. However, research regarding the use of UAVs for flood mapping caused by dam break is still necessary. If UAV images are overlay with high-resolution DEM data, a rich set of thematic flood data can be more exactly extracted and explored.

The overall goal of this study was to analyze the flood-damaged area by dam break with typical hydrologic and hydraulic modeling in ungagged watershed and identify collapse type in actual broken reservoir. The specific objectives of the study were as follows: 1) to generate DSM and reference inundation map from UAV data within reservoir and downstream topographies of actual damaged areas for a $61,400 \mathrm{~m}^{3}$ storage dam that was broken by $92.6 \mathrm{~mm}$ rainfall event with rainfall intensity over $30.0 \mathrm{~mm} / \mathrm{hr}$ on August $21^{\text {st }}, 2014$ for calibration of watershed parameters in the modelling, 2) to simulate two scenarios (overtopping and piping) using HEC-HMS (Hydrologic Engineering Centers Hydrological Modeling System) model, 3) to simulate inundation area using HEC-RAS model from estimated flood discharge, and 4) to identify collapse type compared with inundation map between two scenarios.

\section{Materials and Methods}

\subsection{Study Area and Input Data}

The broken dam is located in the southeastern part of South Korea, with a latitude and longitude of $35.895^{\circ} \mathrm{N}$ and $128.96^{\circ} \mathrm{E}$, respectively. The Goeyeon reservoir dam was built in 1945 for rice paddy irrigation water supply to the downstream area. The dam was broken by the $92.6 \mathrm{~mm}$ rainfall event with over 30 $\mathrm{mm} / \mathrm{hr}$ rainfall intensity in August 21 ${ }^{\text {st }}, 2014$ after reaching the maximum water level to the bank top. The cause of reservoir collapse was predicted as overtopping by the rain storm, but was not certain with piping possibility. Figure 1 shows the location of the reservoir, the part of the broken dam, and the cut section of the bank. Figure 2 shows the GIS input data of the upper watershed of the reservoir for the HEC-HMS modeling.

\subsection{UAV Specification and Imaging Process}

A rotary-wing drone of $3.5 \mathrm{~kg}$ weight carried with the Sony NEX-5T sensors was used to acquire the image data (Figure 3). It has $4 \mathrm{~cm}$ by $4 \mathrm{~cm}$ spatial resolution with JPEG image format. Table 1 shows the specification of the drone. The autopilot flight was applied by the inertial measurement unit (IMU) and onboard GPS. The integration of sensors with IMU and GPS enabled to obtain the geo-referenced images. For post-processing, the DSM was produced by the terra 


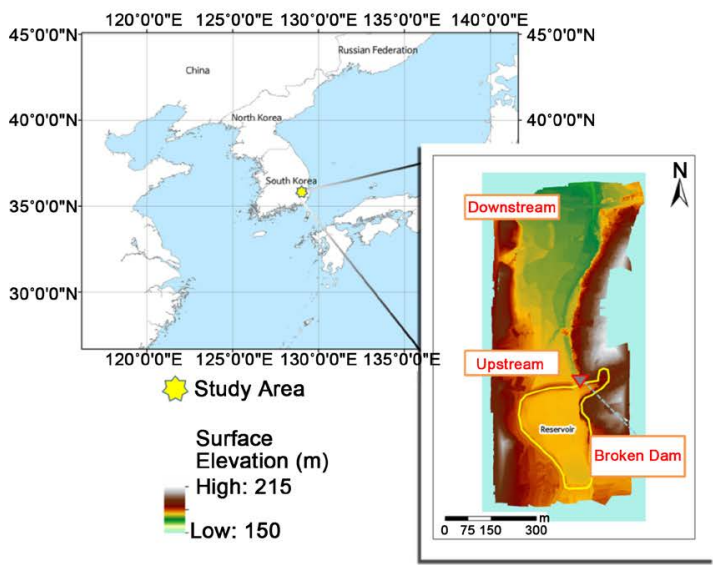

(a)

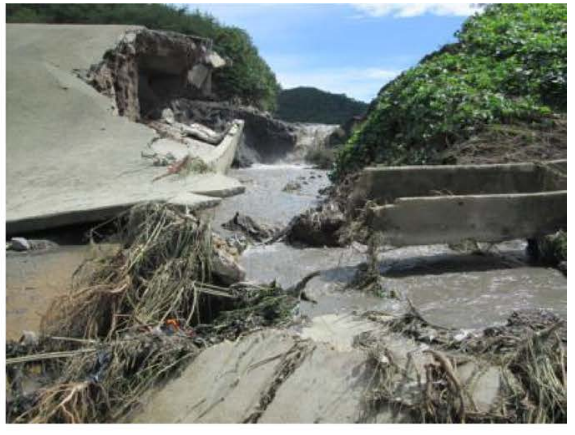

(b)

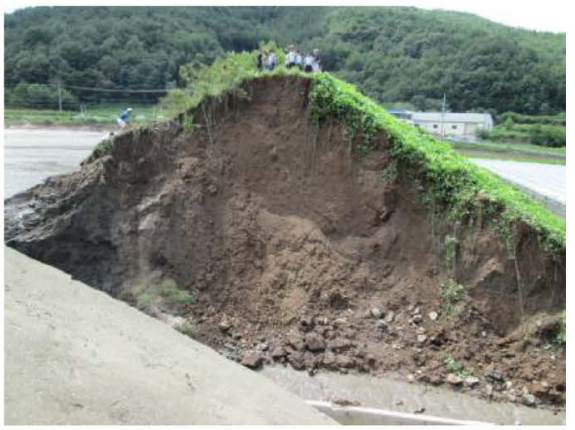

(c)

Figure 1. Location of the study reservoir: (a) Digital Elevation Model, (b) Front view of the broken dam, (c) Side view of the dam cut end.
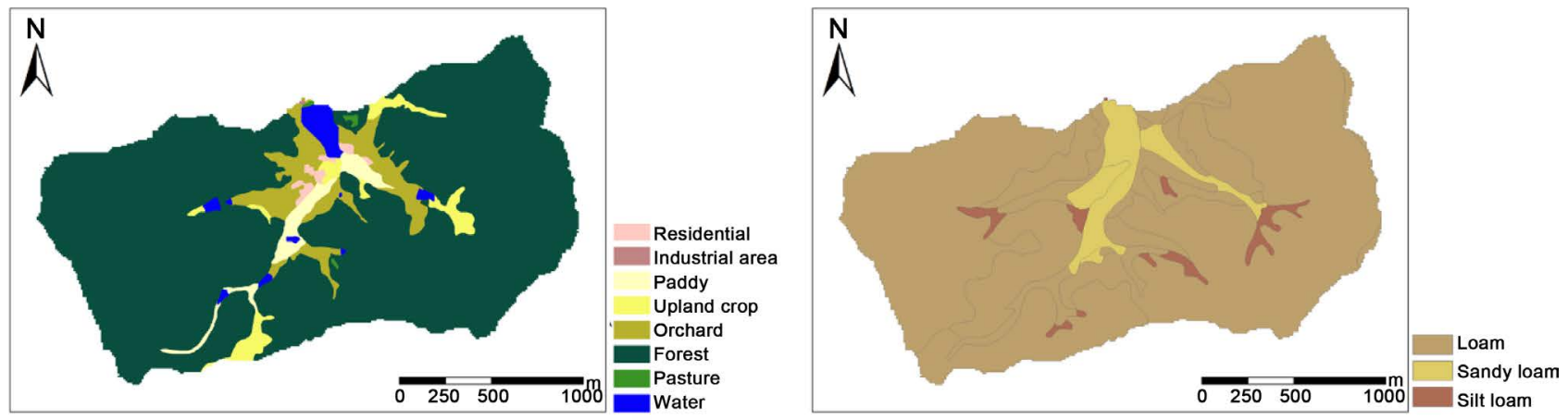

Figure 2. Reservoir watershed data for HEC-HMS modeling: (a) Land use and (b) Soil texture.

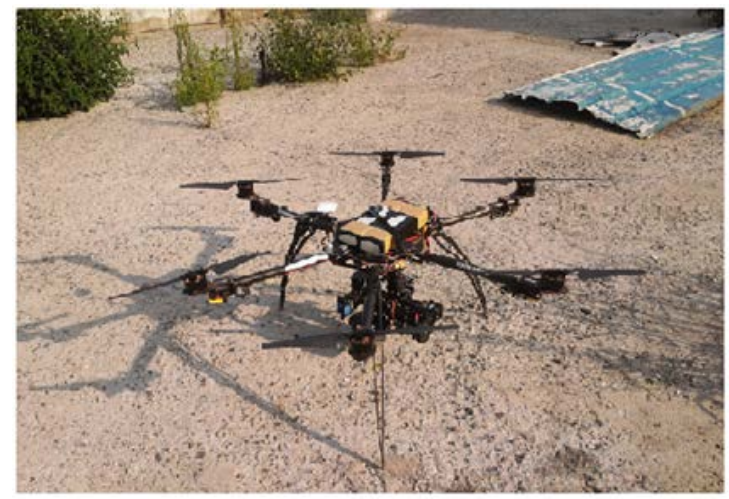

Figure 3. Location of the study watershed and locations of the weather, streamflow, and water quality gauging stations. 
Table 1. Rotary wing drone specifications.

\begin{tabular}{cc}
\hline Divisions & Detail \\
\hline Model & GEO X-10S/E \\
Dimension & $1300 \times 1300 \times 140 \mathrm{~mm}$ \\
Weight & $3.5 \mathrm{~kg}$ \\
Propeller & 8 propellers \\
Image resolution & $(4 \mathrm{~cm} \times 4 \mathrm{~cm}) /$ pixel \\
Sensor & Sony NEX-5T \\
& Terra 3D program \\
Post processing program & (Ortho-image and Digital Surface Model production) \\
& Virtual Surveyor Tools (DSM points convert to CAD file) \\
Civil Pro (Converted points extract contour line) \\
Observation period & August 17 To 21, 2014 \\
\hline
\end{tabular}

3D program. The DSM points converted to CAD file using the Virtual Surveyor Tools and then extracted contour line by using the Civil Pro program.

In order to orient and relate the drone images to the ground, twenty GCPs (Ground Control Points) were investigated and four checking points were arranged for uniform horizontal and vertical accuracy. With $60 \%$ end laps as well as $60 \%$ side laps, the drone routed two times for $0.43 \mathrm{~km}^{2}$ areas with total 338 images of first 153 images and second 185 images respectively. In this study, calibrated and validated UVA geospatial data obtained from the Korea Rural Development Administration (KRDA). Details regarding the estimation process of the UVA geospatial data can be found in Park and Park [18].

\subsection{HEC-HMS and HEC-RAS Model Theory}

HEC-HMS and HEC-RAS were used to develop the dam break and inundation modeling. Numerous previous studies have shown these models to provide accurate and useful results in flood-related studies [19] [20].

The watershed runoff to reservoir was modeled using HEC-HMS. HEC-HMS was developed by the US Army Corps of Engineers and designed to simulate the rainfall-runoff processes of dendritic watershed systems. During the runoff process, the infiltration capacity $\left(I_{a}\right)$ is quantified by the Soil Conservation Service-Curve Number (SCS-CN) based on land use and hydrologic soil group. The runoff is calculated from the following set of empirical equations:

$$
\begin{gathered}
Q=\left(P-I_{a}\right)^{2} /\left(\left(P-I_{a}\right)+S\right) \\
I_{a}=0.2 S \\
S=(1000 / \mathrm{CN})-10 \\
Q=(P-0.2 S)^{2} /(P+0.8 S)
\end{gathered}
$$

where $Q$ is the runoff, $P$ is the rainfall, $S$ is the maximum potential reten- 
tion, $I_{a}$ is the initial abstraction, and $\mathrm{CN}$ is the runoff curve number. The flood wave propagation by dam breakage was modeled using HEC-RAS. HEC-RAS calculates one-dimensional steady and unsteady flow, and the model equations are described by Horritt and Bates [21]. The system requires the output hydrograph from the HMS as input, and the parameters are representative cross-sections, including left and right bank locations, Manning's roughness coefficients, and contraction and expansion coefficients. To develop the floodplain maps, a digital elevation model (DEM) was formed by channel geometry. The flood wave is calculated by the following kinematic wave equation and watershed parameters $\left(K, T_{c}\right)$ are calculated by Kraven and Sabol equations.

$$
\begin{gathered}
Q=V_{1} A_{1}=V_{2} A_{2} \\
Q=C \sqrt{\bar{S}_{f}} \\
C=\frac{1}{n} A R^{2 / 3} \\
K=\frac{T_{c}}{1.46-0.0867 \frac{L^{2}}{A}} \\
T_{c}=0.444 \frac{L}{S^{0.515}}
\end{gathered}
$$

where $Q$ is the flow discharge $\left(\mathrm{m}^{3} / \mathrm{s}\right), V_{i}$ is the average velocity at cross-section $i$ $(\mathrm{m} / \mathrm{s}), \quad A_{i}$ is the area at cross-section $\mathrm{i}\left(\mathrm{m}^{2}\right), \quad R$ is the hydraulic radius $(\mathrm{m}), n$ is Manning's roughness coefficient, $C$ is the conveyance $\left(\mathrm{m}^{5 / 3}\right), \bar{S}_{f}$ is the average friction slope between adjacent cross-sections, $A$ is the watershed area $\left(\mathrm{km}^{2}\right), L$ is the river length $(\mathrm{km}), S$ is the watershed slope, $K$ is the storage constant (hr) from Kraven equation, and $T_{c}$ is the concentration time (hr) from Sabol equation.

\subsection{Dam-Break Simulation Using HEC-HMS}

The dam break was established using HEC-HMS, developed by the US Army Corps of Engineers. HEC-HMS allows the modeler to choose two different methods for computing outflow through two dam-breach options: overtopping and piping.

Two cases were applied in this study because the break cause was unknown. The 'overtopping dam break' is designed to represent failures caused by overtopping of the dam. This failure is most common in earthen dams but may also occur in concrete arch, concrete gravity, or roller-compacted dams as well. The failure begins when the appreciable amount of water begins flowing over or around the dam face. Another method is designed to represent failures caused by piping inside of the dam, called "piping dam-break". This failure typically occurs only in earthen dams. The failure begins when water naturally seeping through the dam core increases in velocity and a sufficient quantity of fine sediment 
moves out of the soil matrix.

If a sufficient amount of material erodes, then a direct piping connection may be established from the reservoir water to the dam face. Once such a piping connection is formed, it is almost impossible to stop the dam from failing. The method begins the failure at a point in the dam face and expands it as a circular opening. When the opening reaches the top of the dam, it continues expanding as a trapezoidal shape. The flow through the circular opening is modeled as orifice flow, whereas it is modeled as weir flow in the second stage [22].

To apply dam break model, we need information on the collapse width, slope, and shape for collapse duration, cause of collapse, inflow hydrograph, and downstream cross section. The Goeyeon reservoir is a small reservoir and has no specifications related to the reservoir. Table 2 summarizes the data of the collapse width and slope data collected through various media. According to the Yeongcheon station from the Meteorological Agency, cumulative rainfall from 7:00 am on August 20, 2014 to 9:00 am on August 21, 2014 is $92.6 \mathrm{~mm}$, and it is confirmed that rainfall has ended before 9:00 am on August 21. Therefore, the reservoir level at the time of the collapse was a high water level, and we applied to the dam break model assuming no additional inflow. Figure 4 shows the rainfall hyetograph at Yeongcheon station during the collapse period. In this study, two collapse scenarios such as piping and overtopping were applied by fixing the collapse width $(20 \mathrm{~m})$, and slope $(1: 1)$ and considering construction year.

Table 2. Reservoir specification and collapse observation information.

\begin{tabular}{|c|c|c|c|c|c|c|c|}
\hline \multicolumn{5}{|c|}{ Collapse information } & \multicolumn{3}{|c|}{ Reservoir information } \\
\hline $\begin{array}{l}\text { Height } \\
\text { (m) }\end{array}$ & $\begin{array}{l}\text { Width } \\
\text { (m) }\end{array}$ & Slope & Dam Type & $\begin{array}{l}\text { Dam crest } \\
\text { (EL. m) }\end{array}$ & $\begin{array}{l}\text { Storage capacity } \\
\qquad\left(\mathrm{m}^{3}\right)\end{array}$ & $\begin{array}{l}\text { Reservoir length } \\
\text { (m) }\end{array}$ & $\begin{array}{c}\text { Drainage area } \\
\text { (ha) }\end{array}$ \\
\hline 5.5 & 20.0 & $1: 1$ & Fill dam & 183.7 & 61,000 & 160.0 & 125.0 \\
\hline
\end{tabular}

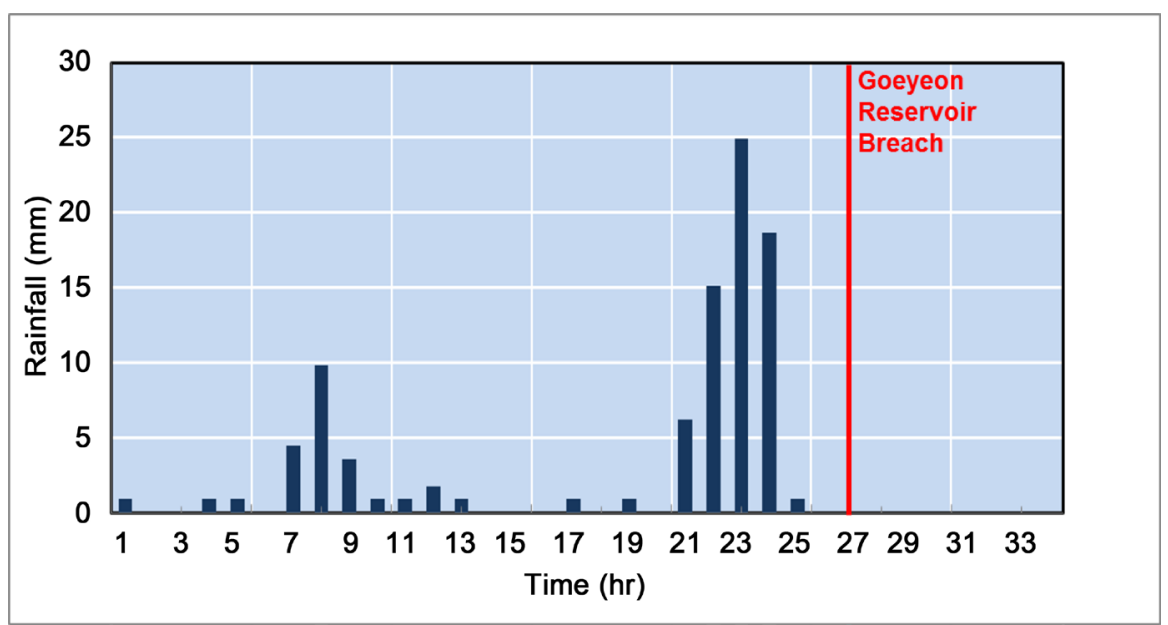

Figure 4. Location of the study watershed and locations of the weather, streamflow, and water quality gauging stations. 


\subsection{Dam-Break Simulation Using HEC-HMS}

The one-dimensional hydraulic model of HEC-RAS is widely and commonly used to analyze the water surface profile, flow characteristics, and hydraulic structure. HEC-RAS computes the water surface elevation and velocity at successive cross-sections by solving continuity, energy, and flow resistance equations in a scheme called the standard step-backwater method [3] [23]. In this study, the excess water from the broken dam calculated by HEC-HMS was applied to HEC-RAS as a boundary condition, and the flood inundation map was visualized using the HEC-GeoRAS module, the extended module of ArcView and ArcMap and developed by Hydrologic Engineering Center of U.S. Army Corps of Engineers and ESRI (Environmental Systems Research Institute). The basic structural dam information, watershed-and reservoir-related data, and downstream topographic data were collected from a national [24]. Figure 5 shows the flowchart of the study.

\subsection{Digital Surface Model and Elevation-Storage Curve: UAV Observations}

Using the UAV, the DSM (Digital Surface Model) was obtained on August 21 $1^{\text {st }}$, 2014 under the broken dam with almost empty reservoir and downstream damaged area exposed condition. The DSM data were collected from a UAV to extract the detailed topography of the channel and inside the reservoir to ensure reliable hydraulic modeling results (Figure 6). Most of the reservoirs in South Korea were located at valley. These reservoirs of valley type have no actual survey data as well as satellite and aerial image data. Therefore, UAV images have the advantage of being able to accurately analyze the damage situation by capturing the disaster area in a timely manner when it is needed. In this study, we used the

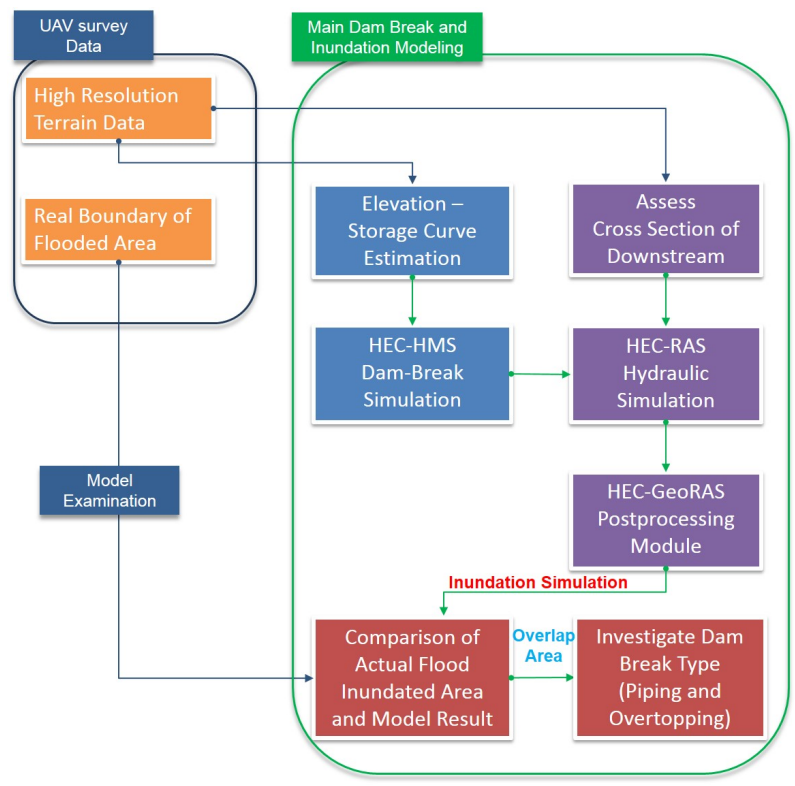

Figure 5. Flow chart of thist study. 
UAV images taken by Park and Park [18] to create accurate topographic and flood trace maps. In addition, we created a precise topographic map by using Google images before the collapse of the reservoir. These two topographical maps (Figure 6(b)) were used to compare and analyze the situation before and after the collapse of the reservoir. In particular, the elevation-storage curve was calculated via the DSM using Equations ((8) and (9)) (Figure 7 and Figure 8). The UAV reservoir terrain detection was possible because the land surface was exposed by the dam break. In this study, the relationship between the reservoir surface area and the reservoir storage was derived by using the DSM from UAV image, Equation (10), and Equation (11) (Figure 8).

$$
\begin{gathered}
\text { Volume }_{m}=\sum\left(\text { Cell }_{m} \times \text { Volume }_{\text {cell }}\right) \\
\text { Volume }_{a}=\text { Volume }_{m(=\text { min })}+\cdots+\text { Volume }_{m(=\text { spec })}
\end{gathered}
$$

where Volume $_{m}$ is the volume of water at each unit elevation (meter), Volume $e_{\text {cell }}$ is the volume of each unit cell, Volume ${ }_{a}$ is the accumulated volume from the minimum to a specific elevation, Volume $_{m(-m i n)}$ is the volume when the water elevation is 1 , and Volume $e_{m(=s p e c)}$ is the volume when the water reaches to a specific elevation. Because the volume of each unit cell is $1 \mathrm{~m}^{3}(1 \mathrm{~m}$ length $\times 1 \mathrm{~m}$

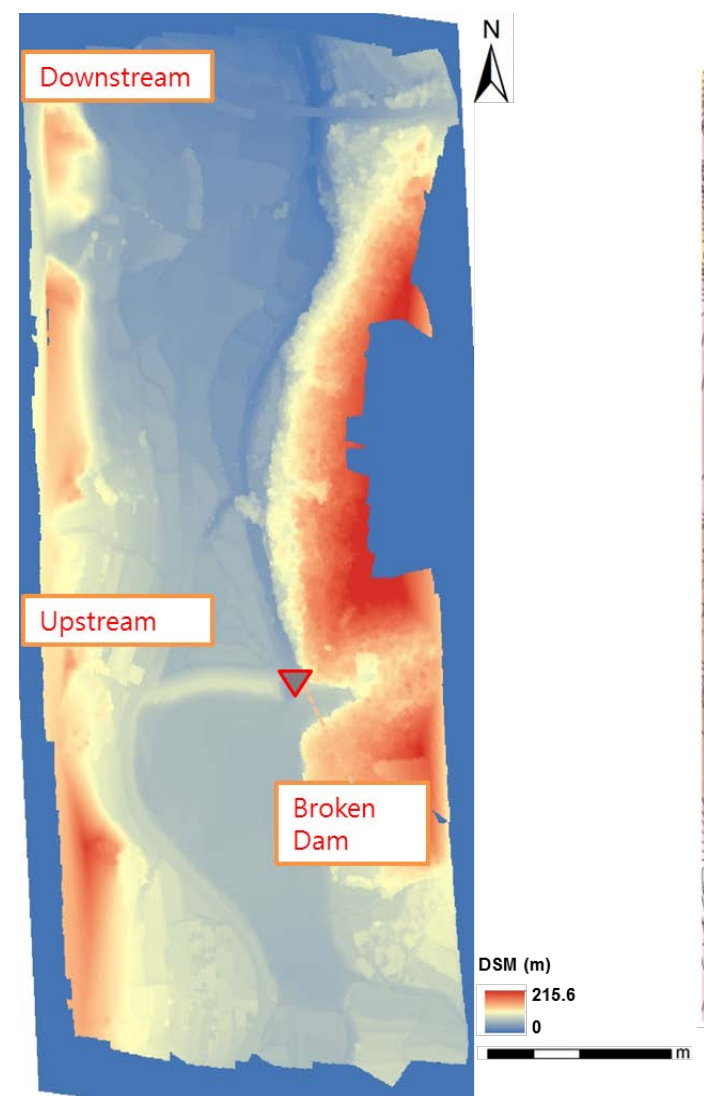

(a)

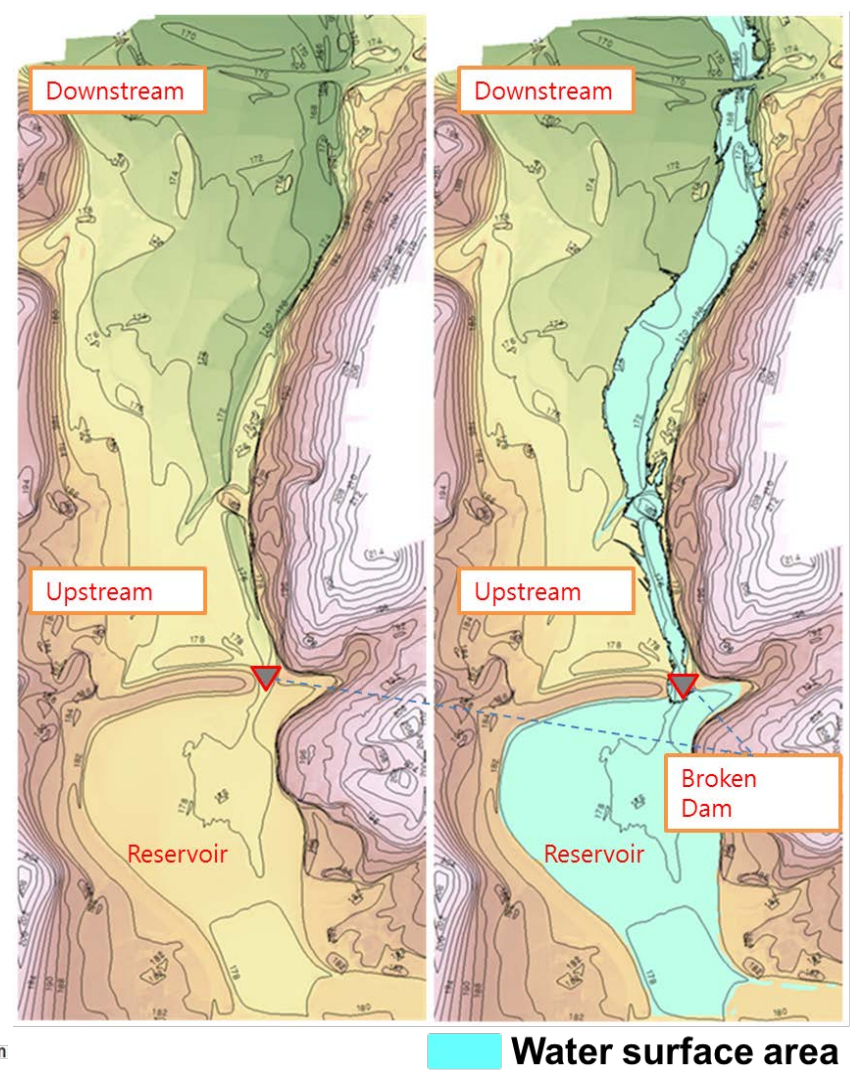

(b)

Figure 6. Distribution maps: (a) DSM derived by UAV (b) High-resolution topographical map derived by DSM (Right). 


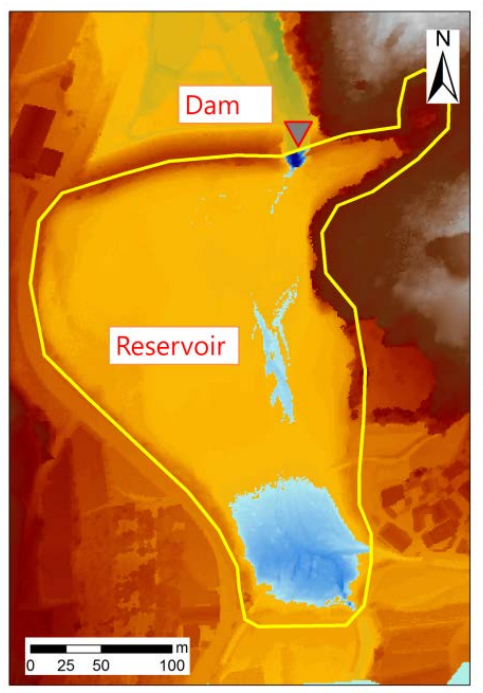

(a)

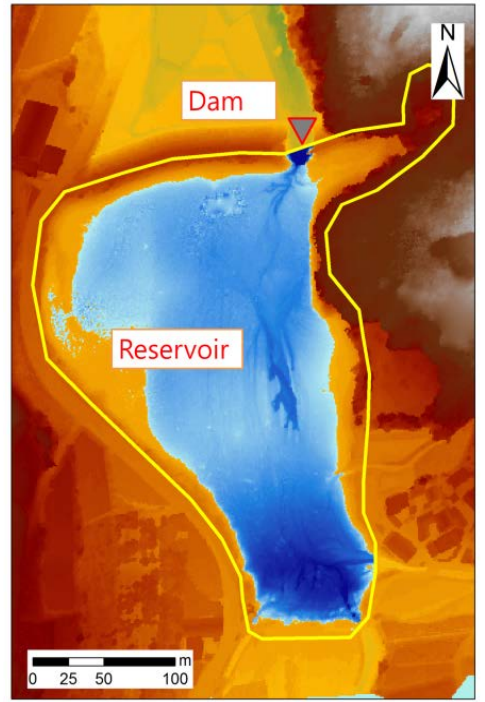

(c)

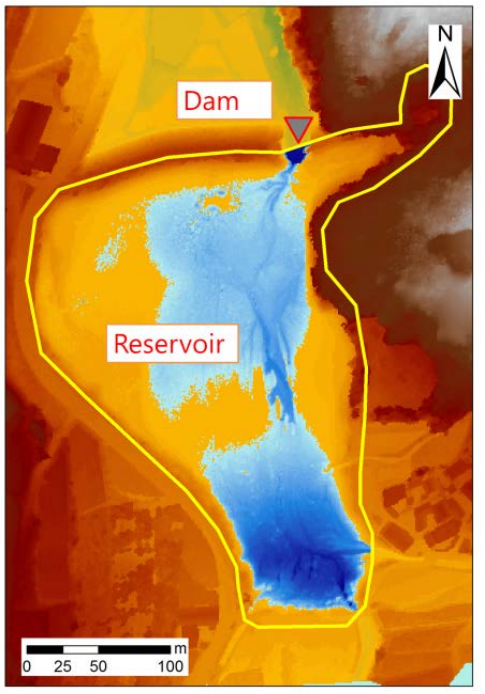

Water Elevation (m) High : 4

(b)

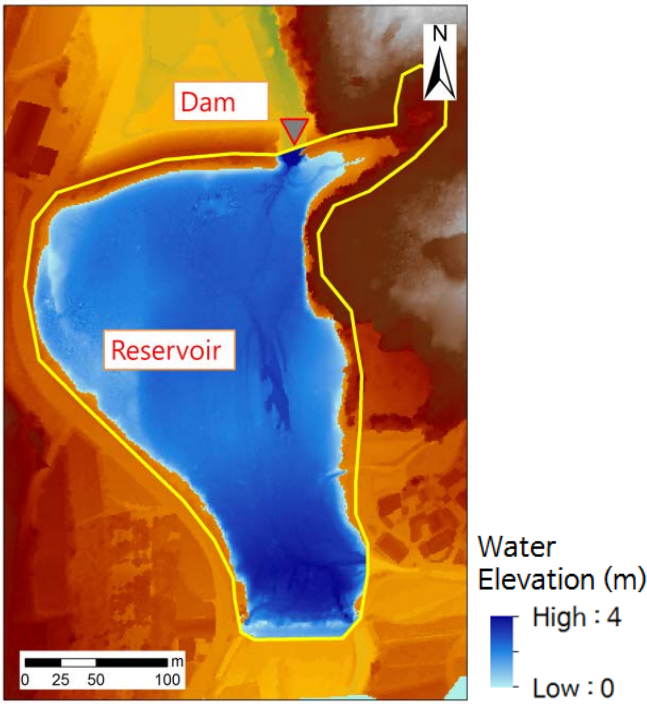

(d)

Figure 7. Reservoir water surface areas to estimate reservoir volume using drone derive DSM for reservoir elevation-area-volume graph (a) to $2.0 \mathrm{~m}$ (elevation: $\mathrm{m}$ ), (b) to $2.4 \mathrm{~m}$, (c) to $2.8 \mathrm{~m}$, and to $4.0 \mathrm{~m}$ from reservoir bottom as zero.

width $\times 1 \mathrm{~m}$ depth), the depth value of cell is equal to its volume.

The reported irrigation area of the reservoir is 125 ha and the effective storage capacity is $61,000 \mathrm{~m}^{3}$. Because of the lack of basic data such as dam minimum and maximum water levels in reservoir, we estimated water level in reservoir using accurate topographic map. The estimates of the topographic maps are overestimated. In order to calibrate this, we have derived the water level-water surface relation by setting the reported effective storage capacity of $61,000 \mathrm{~m}^{3}$ to the maximum water level. As a result, the minimum water level is EL. $176.77 \mathrm{~m}$. The area and the storage capacity of each water level are shown in Table 3 and Figure 8. 
Table 3. Estimated water level-surface area and storage capacity.

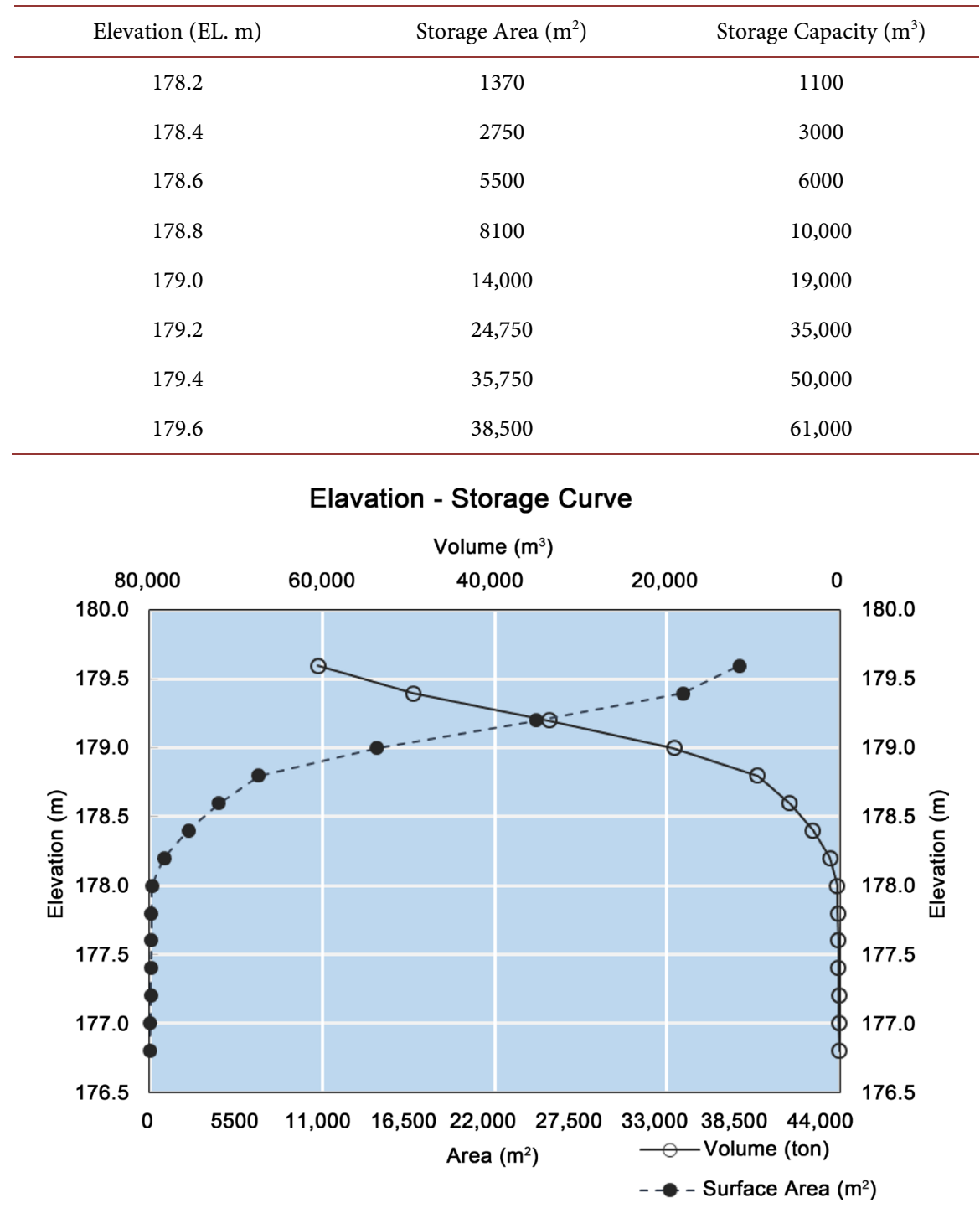

Figure 8. The estimated relationship between reservoir elevation-area-volume a graph using drone derived DSM.

\section{Results and Discussion}

\subsection{Calibration of Watershed Parameters in Ungagged Watershed from HEC-HMS}

Calibration of the model with appropriate data is a crucial step in the creation of a reliable basin representation. Watershed parameters such as infiltration coefficients, time of concentration, and baseflow may need modification to produce a best fit between model and observations. However, this study watershed as ungagged watershed has not directly measured runoff at reach or reservoir inflow. So, watershed parameters such as $\mathrm{CN}, \mathrm{K}$, TC were calculated from Equations ((3), (8), and (9)) without optimization process with observed runoff. Nevertheless, because the model calibration process is necessary, the watershed parameters 
were adjusted using actual flood map from UAV images. Table 4 shows the final watershed parameters and watershed characteristics.

\subsection{HEC-HMS Dam Breach and HEC-RAS Inundation Modeling}

Figure 9 shows the discharge of water with 2 dam-break scenarios; (a) overtopping and (b) piping. According to the national hazard investigation report [24], the initial reservoir water level was set to $98 \%$ of full water level. The duration time of dam failure was set to $30 \mathrm{~min}$. Under the condition of maximum 61,400 $\mathrm{m}^{3}$ reservoir storage amount pouring to the downstream area, the peak discharge was up to $107.9 \mathrm{~m}^{3} / \mathrm{sec}$ by overtopping and $140.2 \mathrm{~m}^{3} / \mathrm{sec}$ by piping failure, respectively. To calculate the downstream inundation area and depth, HEC-RAS used the HEC-HMS flood wave discharges of Figure 8 as the boundary conditions, and the results were represented by HEC-GeoRAS. Figure 9 shows the estimated flood mapping results with two dam-break scenarios. To evaluate the performance of the model, the F statistic used Equation (12) to compare the drone and HEC-RAS inundation areas [3] [20] [25].

$$
F=\left(\frac{A_{o p}}{A_{o}+A_{p}-A_{o p}}\right) \times 100
$$

where $A_{o}$ is the UAV observed area of inundation, $A_{p}$ is the HEC-RAS-predicted area of inundation, and $A_{o p}$ is the overlapped area between $A_{o}$ and $A_{p}$. The

Table 4. Reservoir specification and collapse observation information.

\begin{tabular}{cccccc}
\hline \multicolumn{3}{c}{ Watershed characteristics } & \multicolumn{3}{c}{ Reservoir information } \\
\hline Area $\left(\mathrm{km}^{2}\right)$ & $\mathrm{L}(\mathrm{km})$ & Slope $(\%)$ & $\mathrm{CN}$ & $\mathrm{Tc}(\mathrm{hr})$ & $\mathrm{K}(\mathrm{hr})$ \\
\hline 4.9 & 3.2 & 34.9 & 86.7 & 2.44 & 1.91 \\
\hline
\end{tabular}

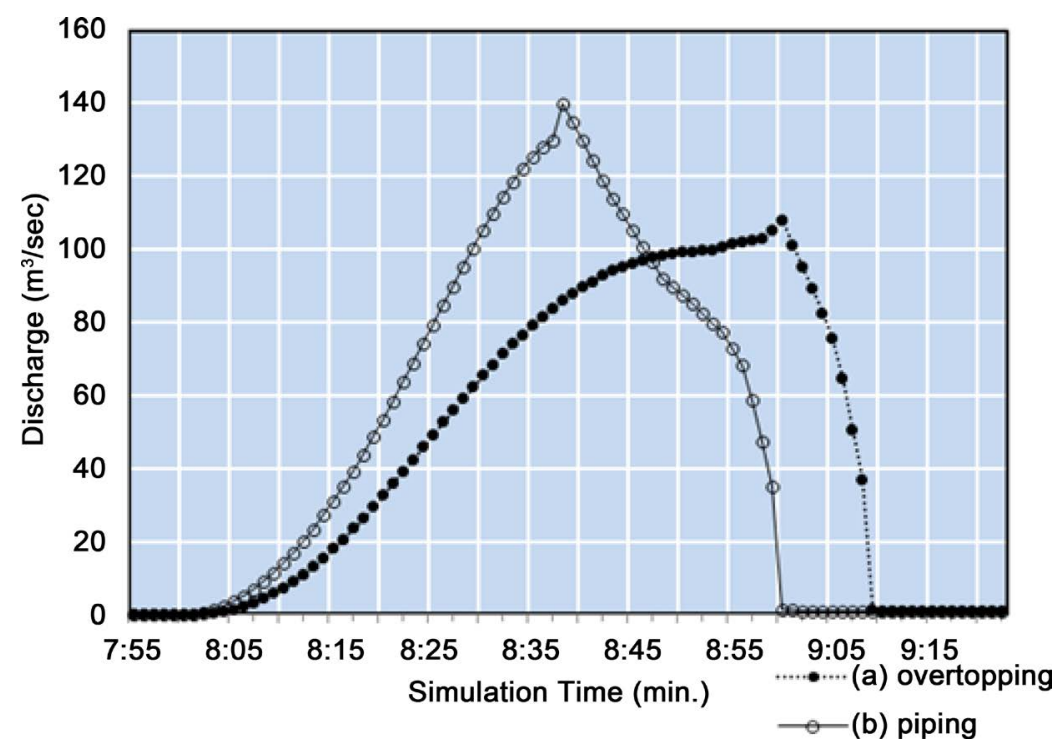

Figure 9. Flood wave discharge graph by dam-break using HEC-HMS: Case of (a) Overtopping and (b) Piping. 
F statistic varies from " 100 " when observed and predicted areas coincide perfectly to " 0 " when there is no overlap between the predicted and observed areas.

The inundation map indicated using UAV is the actual observation data, so it can be seen as flood trace. Two methods were used to evaluate flood inundation according to the collapse runoff of Goeyeon reservoir for the most suitable floodplain. The first is a simple comparison by area, and the second is the comparison of the flood trace using the Lee Sallee Shape Index (LSSI) method. The LSSI method is a method of measuring the degree of agreement between two data by overlapping the reference data with the measurement data [26]. In other words, the intersection area between the two data is divided by the union area, and the value is calculated as the generalized index. The index means indicator that measures the degree of spatial alignment between two data. The reference data in this study is flood trace from UAV and the measured data is each scenario result (Table 5). Figure 10 shows the UAV observed damaged areas with

Table 5. Results of dam-break scenarios.

\begin{tabular}{ccccccc}
\hline Scenario & Flood area $\left(\mathrm{m}^{2}\right)$ & $\mathrm{F}(\%)$ & $\mathrm{A}-\mathrm{B}\left(\mathrm{m}^{2}\right)$ & $\mathrm{A} \cap \mathrm{B}\left(\mathrm{m}^{2}\right)$ & $\mathrm{A} \cup \mathrm{B}\left(\mathrm{m}^{2}\right)$ & $\mathrm{A} \cap \mathrm{B} / \mathrm{A} \cup \mathrm{B}$ \\
\hline Piping (B) & $15,931.3$ & 54.8 & 3084.9 & 8857.2 & $16,398.2$ & 0.54 \\
Overtopping (B) & $11,918.4$ & 59.0 & 2077.9 & 9864.2 & $12,552.9$ & 0.79 \\
Observed UAV (A) & $11,941.9$ & & & & & \\
\hline
\end{tabular}

A: Inundation trace map using UAV, B: Flood inundation maps by scenario.

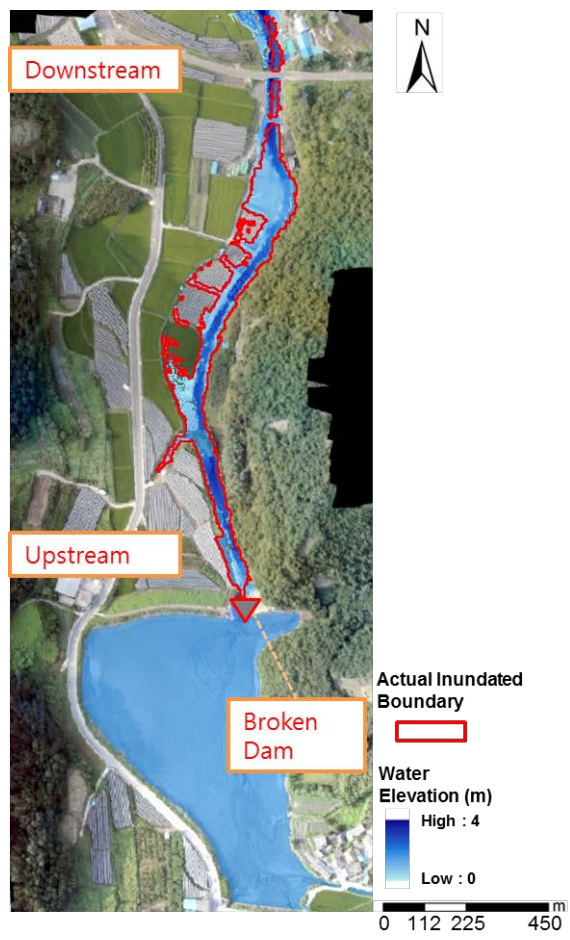

(a)

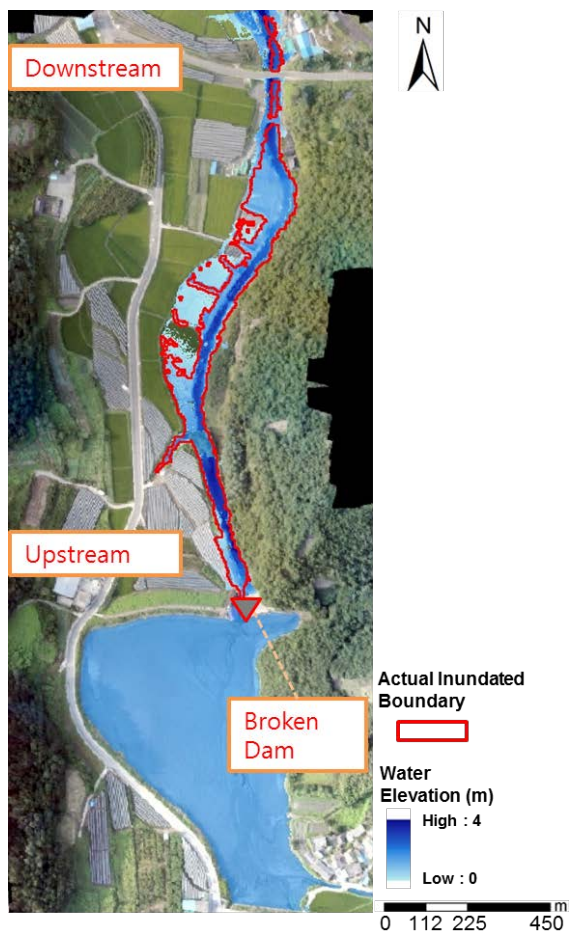

(b)

Figure 10. The HEC-RAS simulated inundation areas and depth distributions in case of (a) Overtopping and (b) Piping dam break conditions. 
11,941.9 $\mathrm{m}^{2}\left(A_{o}\right)$ and the HEC-RAS dam break simulated damaged areas for (a) overtopping with $11,918.4 \mathrm{~m}^{2}\left(A_{p_{-} \text {over }}\right)$ and (b) piping with $15,931.3 \mathrm{~m}^{2}\left(A_{p_{-} \text {pipe }}\right)$ respectively. The UAV overlapped areas for overtopping $\left(A_{\text {op_over }}\right)$ and piping ( $A_{\text {op_pipe }}$ ) simulations were $9864 \mathrm{~m}^{2}$ and $8857 \mathrm{~m}^{2}$ with $\mathrm{F}$ values of $59.0 \%$ and $54.8 \%$ respectively.

For overtopping dam break, the flood depth ranged from 0.1 to $2.2 \mathrm{~m}$ after the peak discharge of 15 - 20 mins. As seen in Figure 10, the piping dam-break scenario simulated more inundation areas especially in the middle of the downstream area as the peak discharge was $32.3 \mathrm{~m}^{3} / \mathrm{sec}$ higher than that in the overtopping scenario. Thus, we can infer that the dam would be broken by overtopping phenomenon. Looking at the areas between UAV and overtopping damaged areas, the difference increased at the end of downstream area. The errors may come from the road location crossing the stream at the end of downstream and the flood discharges along the roads. Otherwise, there is a possibility that the rice paddies at the downstream areas were inundated but they were not damaged by the flood wave attenuation.

\section{Summary and Conclusions}

In this study, the flood-damaged areas caused by a dam-break accident were investigated using a UAV, and the collected data were compared with the HEC-RAS simulation results. For a small agricultural reservoir of $61,400 \mathrm{~m}^{3}$ water storage broken by $89.0 \mathrm{~mm}$ rainfall event in August $21^{\text {st }}, 2014$, the 2 dam-break scenarios of overtopping and piping were tested. To estimate the HEC-HMS parameters for the elevation-storage relationship of the reservoir, the high-resolution DSM was collected from drone surveying. The dam-break results by HEC-HMS were transferred to the HEC-RAS as the boundary conditions, and the flood areas and depth were expressed by using the HEC-GeoRAS module over the DSM map.

The peak discharges for overtopping and piping failure were $107.9 \mathrm{~m}^{3} / \mathrm{sec}$ and $140.2 \mathrm{~m}^{3} / \mathrm{sec}$, respectively, with flood inundation depths of $0.1-2.2 \mathrm{~m}$ in the downstream area. From the distribution of the inundation areas from each dam-break scenario, we could infer that the dam was broken by the overtopping phenomenon. The discordance between the areas increased when it goes to the downstream area. The paddy rice near the dam was lodged by the fast velocity of the flood wave, but the far-downstream rice was less affected by the attenuated flood wave and recovered after drainage. In addition, the UAV surveying proved to be a valuable tool for the identification of flood-damaged areas and for economic loss evaluation.

The result of the dam-break in this study showed that the reservoir collapsed by overtopping. Overall, we proposed the application method of UAV data in ungagged area such as small reservoir watershed. The result from this study can be used to predict the risk of collapse of old and small reservoirs. Therefore, small and old reservoirs must once again make a safety review in ungagged area 
where flooding has occurred in the past using UAV and modeling to prevent reservoir collapse. Then, action plan is provided for each reservoir level.

\section{Acknowledgements}

This research was supported by a grant (17AWMP-B079625-04) from the Water Management Research Program funded by the Ministry of Land, Infrastructure and Transport of the Korean government.

\section{References}

[1] You, L., Li, C., Min, X. and Xiaolei, T. (2012) Review of Dam-Break Research of Earth-Rock Dam Combining with Dam Safety Management. Procedia Engineering, 28, 382-388. https://doi.org/10.1016/j.proeng.2012.01.737

[2] Carling, P., Villanueva, I., Herget, J., Wright, N., Borodavko, P. and Mornav, H. (2010) Unsteady 1D and 2D Hydraulic Models with Ice Dam Break for Quaternary Megaflood, Altia Mountains, Southern Siberia. Global Planet Change, 70, 24-34. https://doi.org/10.1016/j.gloplacha.2009.11.005

[3] Sarhadi, A., Soltani, S. and Modarres, R. (2012) Probabilistic Flood Inundation Mapping of Ungauged Rivers: Linking GIS Techniques and Frequency Analysis. Journal of Hydrology, 458-459, 68-86. https://doi.org/10.1016/j.jhydrol.2012.06.039

[4] Evangelista, S.L., Altinakar, M., Cristo, C.D. and Leopardi, A. (2013) Simulation of Dam-Break Waves on Movable Beds Using a Multi-Stage Centered Scheme. International Journal of Sediment Research, 28, 269-284. https://doi.org/10.1016/S1001-6279(13)60039-6

[5] Prakash, M., Rothauge, K. and Cleary, P.W. (2014) Modelling the Impact of Dam Failure Scenarios on Flood Inundation Using SPH. Applied Mathematical Modelling, 38, 5515-5534. https://doi.org/10.1016/j.apm.2014.03.011

[6] Li, M., Shao, Q., Zhang, L. and Chiew, F.H.S. (2010) A New Regionalization Approach and Its Application to Predict Flow Duration Curve in Ungauged Basins. Journal of Hydrology, 389, 137-145. https://doi.org/10.1016/j.jhydrol.2010.05.039

[7] Noman, N.S., Nelson, E.J. and Zundel, A.K. (2001) Review of Automated Floodplain Delineation from Digital Terrain Models. Journal of Water Resources Planning and Management, 127, 394-402. https://doi.org/10.1061/(ASCE)0733-9496(2001)127:6(394)

[8] Martinez, J.M. and Toan, T.L. (2007) Mapping of Flood Dynamics and Spatial Distribution of Vegetation in the Amazon Floodplain Using Multi-Temporal SAR Data. Remote Sensing of Environment, 108, 209-223. https://doi.org/10.1016/j.rse.2006.11.012

[9] Sanders, B.F. (2007) Evaluation of On-Line DEMs for Flood Inundation Modeling. Advances in Water Resources, 30, 1831-1843. https://doi.org/10.1016/j.advwatres.2007.02.005

[10] Schumann, G. (2007) High-Resolution 3-D Flood Information from Radar Imagery for Flood Hazard Management. IEEE Transactions on Geoscience and Remote Sensing, 45, 1715-1725. https://doi.org/10.1109/TGRS.2006.888103

[11] Aggett, G.R. and Wilson, J.P. (2009) Creating and Computing a High-Resolution DTM with a 1-D Hydraulic Model in GIS for Scenario-Based Assessment of Avulsion Hazard in Grave-Bed River. Geomorphology, 113, 21-34. 
[12] Chen, Y.D., Hill, A.A. and Urbano, L.D. (2009) A GIS-Based Model for Urban Flood Inundation. Journal of Hydrology, 373, 184-192.

[13] Geerling, G.W., Vreeken-Buijs, M.J., Jesse, P., Ragas, A.M.J. and Smits, A.J. (2009) Mapping River Floodplain Ecotopes by Segmentation of Spectral (CASI) and Structural (LiDAR) Remote Sensing. River Research and Applications, 25, 795-813. https://doi.org/10.1002/rra.1181

[14] Li, Y., Gong, J.H., Zhu, J., Ye, L., Song, Y.Q. and Yue, Y.J. (2012) Efficient Dam Break Flood Simulation Methods for Developing a Preliminary Evacuation Plan after the Wenchuan Earthquake. Natural Hazards and Earth System Sciences, 12, 97-106. https://doi.org/10.5194/nhess-12-97-2012

[15] Kääb, A. and Leprince, S. (2014) Motion Detection using Near-Simultaneous Satellite Acquisitions. Remote Sensing of Environment, 154, 164-179.

[16] Tauro, F., Petroselli, A. and Arcangeletti, E. (2015) Assessment of Drone-Based Surface Flow Observations, Hydrological Processes.

[17] Detert, M. and Weitbrecht, V. (2015) A Low-Cost Airborne Velocimetry System: Proof of Concept. Journal of Hydraulic Research, 53, 532-539. https://doi.org/10.1080/00221686.2015.1054322

[18] Park, J.K. and Park, J.H. (2015) Reservoir Failure Monitoring and Identified by the UAV Aerial Images. Journal of Hydraulics Engineering, 11, 155-167. (In Korean)

[19] Ahrens, S.R. and Maidment, D.R. (1999) Flood Forecasting for the Buffalo Bayou using CRWR-PrePro and HEC-HMS (CRWR Report 99-6). Center for Research in Water Resources, Austin.

[20] Anderson, M.L., Chen, Z.Q., Kavvas, M.L. and Feldman, A. (2002) Coupling HEC-HMS with Atmospheric Models for Prediction of Watershed Runoff. Journal of Hydrologic Engineering, 7, 312-318. https://doi.org/10.1061/(ASCE)1084-0699(2002)7:4(312)

[21] Horritt, M.S. and Bates, P.D. (2002) Evaluation of 1D and 2D Numerical Models for Predicting River Flood Inundation. Journal of Hydrology, 268, 87-99.

[22] US Army Corps of Engineers (2010a) HEC-HMS User's Manual. US Army Corps of Engineers, Davis.

[23] US Army Corps of Engineers (2010b) HEC-RAS User's Manual. US Army Corps of Engineers, Davis.

[24] Korea Rural Community Corporation (2014) National Hazard Investigation Report. Korea Rural Community Corporation, South Korea. (In Korean)

[25] Bates, P.D. and De Roo, A.P.J. (2000) A Simple Raster-Based Model for Flood Inundation Simulation. Journal of Hydrology, 236, 54-77.

[26] Clarke, K.C., Hoppen, S. and Gaydos, L.J. (1996) Method and Techniques for Rigorous Calibration of a Cellular Automaton Model of Urban Growth. Proceedings, 3 rd International Conferencel Workshop on Integrating Geographic Information Systems and Environmental Modeling, Santa Fe, 21-25 January 1996. 